\title{
Determinants of operational and maintenance costs of condominiums
}

\author{
B.A.K.S. Perera ${ }^{1}$, I.M.Chethana.S. Illankoon ${ }^{2}$, and W.A.N. Perera ${ }^{3}$ \\ Department of Building Economics \\ Faculty of Architecture, University of Moratuwa, Sri Lanka \\ pererabaks@gmail.com
}

\begin{abstract}
It is important to determine the factors which affect the operational and maintenance costs of condominiums in order to minimize them. Furthermore this would assist the building managers in preparing realistic maintenance budgets in respect of each operational and maintenance activities in the appropriate time. Therefore, this study proposes a framework to control the operational and maintenance costs of condominiums built in Sri Lanka by identifying their determinants.
\end{abstract}

A preliminary survey was initially carried out among six experienced professionals from the industry and it was followed by distributing 35 questionnaires also among professionals from the industry. The Analytical Hierarchical Process and the Relative Importance Index were used to analyze the data gathered.

The findings of the study show that the dominant factors which affect the operational and maintenance costs of condominiums were 'Expectations of Tenants', 'Building Services' and 'Building Finishes'. It was found that 'Including maintenance standards in the Tenancy Agreement' and 'Finding means of increasing service efficiency' are the main important actions that control the seven determinants that have been identified as the most important.

The framework developed through this research enables the identification of the determinants which govern the maintenance and operational costs of condominiums and the actions that control them.

Keywords: Operating Costs, Building Maintenance, Controls.

\section{Introduction to condominiums}

Large cities are being increasingly built in Asia, where scarcity of land resulting from rapid urbanisation compels residential development to take up a high-rise and high-density form (Yip and Forrest, 2002). Further, the increasing popularity of owner occupation in the last couple of decades has made condominiums the most prevalent and popular form of residential development (Yip et al., 2007). The word 'Condominium' is a combination of two Latin words which identify two distinct features of condominium living that is individuality and commonality (Edirimane, 2006). According to Edirimane (2006), condominiums provide a more secure and safer environment for their occupants compared to other types of dwellings and this has become the prime reason for many people in Sri Lanka to move into condominium housing.

The Section 2 of the Apartment Ownership Act No.11 of 1999 defines a Condominium as a property having land with a building or buildings of more than one storey and having more than one unit residential or nonresidential accommodation. The Common Amenities Board Act No. 24 of 2003 has classified condominiums in Sri Lanka under four categories, i.e residential, commercial, industrial, and mixed-use. Residential 
condominiums which are in high demand in Sri Lanka, could again be subdivided in to four categories, viz., super luxury, luxury, semi luxury, or utility (Wijeyweere, 2004 cited Sampath, 2011).

Studies on condominiums have become important as they play a vital role in the Sri Lankan economy (Senaratne et al., 2006). Further, a study by Ariyawansa (2007) has shown that some condominium development work in Sri Lanka; such as those related to Havelock City, Royal Park, Crescat and Kings Court have triggered investigations in to such work. Ariyawansa $(2007$, p.11) has therefore stated that in respect of available market opportunities in the Colombo metropolitan area, condominium development related researches can be quite useful. However as far as their running costs are concerned, despite their significance, condominiums have now become the most affected among the different types of real estate development. (Olubodun and Mole, 1999) This is because of the emphasis placed by both the occupants and maintenance teams of condominiums on the quality and the optimum performance of their health, safety and environmental related facilities instead of their Operational and Maintenance (O \& M) costs. (Ali et al., 2010; Emma and Syahrul, 2009; Williams, 1996). If the running costs of condominiums are to be reduced, there should be more focus on their operational and maintenance related features. Therefore, as pointed out by Ali et al. (2010), it will be important to identify the determinants affecting $\mathrm{O} \& \mathrm{M}$ costs of condominiums as well as the steps that can be taken to control and minimize their effects.

In this research, super luxury and luxury condominiums coming under the category of residential condominiums for which there is currently a high demand and supply, are analyzed to identify the dominant factors affecting the maintenance and operational costs of their modern facilities.

\section{O \& M Costs of condominiums: Their Determinants and Controlling Actions}

Buildings start aging from the time they are completed and put to use (Horner et al., 1997). It is necessary to maintain them properly if their effective and economic use is to be ensured (Simoes et al., 2011). Building operational activities are routine functions that are undertaken for hygienic, aesthetic and security purposes, and for the supply of utilities (Goodman, 2004) which, according to Sliteen et al., (2011), are necessary to keep the building in a habitable and usable condition. In the real estate industry, maintenance and operations are combined and called $\mathrm{O} \& \mathrm{M}$ since a facility cannot operate at its maximum efficiency without being properly maintained (Stoy and Kytzia, 2008).

Operational and maintenance work of a building is considered as a service that the landlord or the management company has to provide to its tenants (Lai et al., 2008). The scope of this work includes the activities required to keep the entire built environment as recorded in the organization's Real Property Inventory of facilities and their supporting infrastructure, including utility systems, parking lots, roads, drainage systems and grounds in a condition that meets their intended functions during their expected life cycles (Bardey et al., 2005).

According to Goodman (2004) and Eisenstadt (1972), the operational and maintenance cost components of condominiums include capital expenditure along with salaries, insurance fees, taxes, utility fees, management fees, administrative, marketing and contract service fees and repair/maintenance fees. Komonen (2002) has stated that operational and maintenance costs of the condominiums are the costs associated with their day-to-day repair and preventive and improvement work. They are related to the direct cost of items required for maintenance such as material, labour, plants and tools as well as to its indirect costs such as 
management costs and administrative and overhead costs needed for the successful completion of the work (El-Haram and Horner, 2002). As a sum up of all these aspects Lai and Yik (2008) have identified $\mathrm{O} \& \mathrm{M}$ costs as a combination of four major cost components, namely, repair and maintenance cost, capital investment cost, administration and staff cost, and water and energy cost.

Identification of factors affecting O\&M costs

The studies of Lai and Yik (2008) have identified factors affecting O \& M costs under two headings: service quality and scale of work. However, according to researchers (O'Neill, 1974; Skinner, 1982; Neveset al., 2004; Wong, 2002; Shabha, 2003; Cheung and Kyle, 1996; Love and Irani, 2003; Khalid et al., 2006; Al-hammad et al., 1996; Pascual et al., 2008; Olubodun, 2001; Lee and Scott, 2009; Ali, 2009; Yip, 2001; Olubodun and Mole, 1999; Al-Arjani, 1995; Wordsworth, 2001; Thompson, 1994), there are several factors that affect $O \& M$ costs of condominiums. In summary, determinants of O\&M costs can widely be discussed under five broad categories, that is, building characteristics, maintenance factors, tenant factors, regulatory and economic factors and other factors (Refer Figure 1). Further based on the literature findings, the researcher has further summarized the relevant sub factors of each category as illustrated in Figure 1.

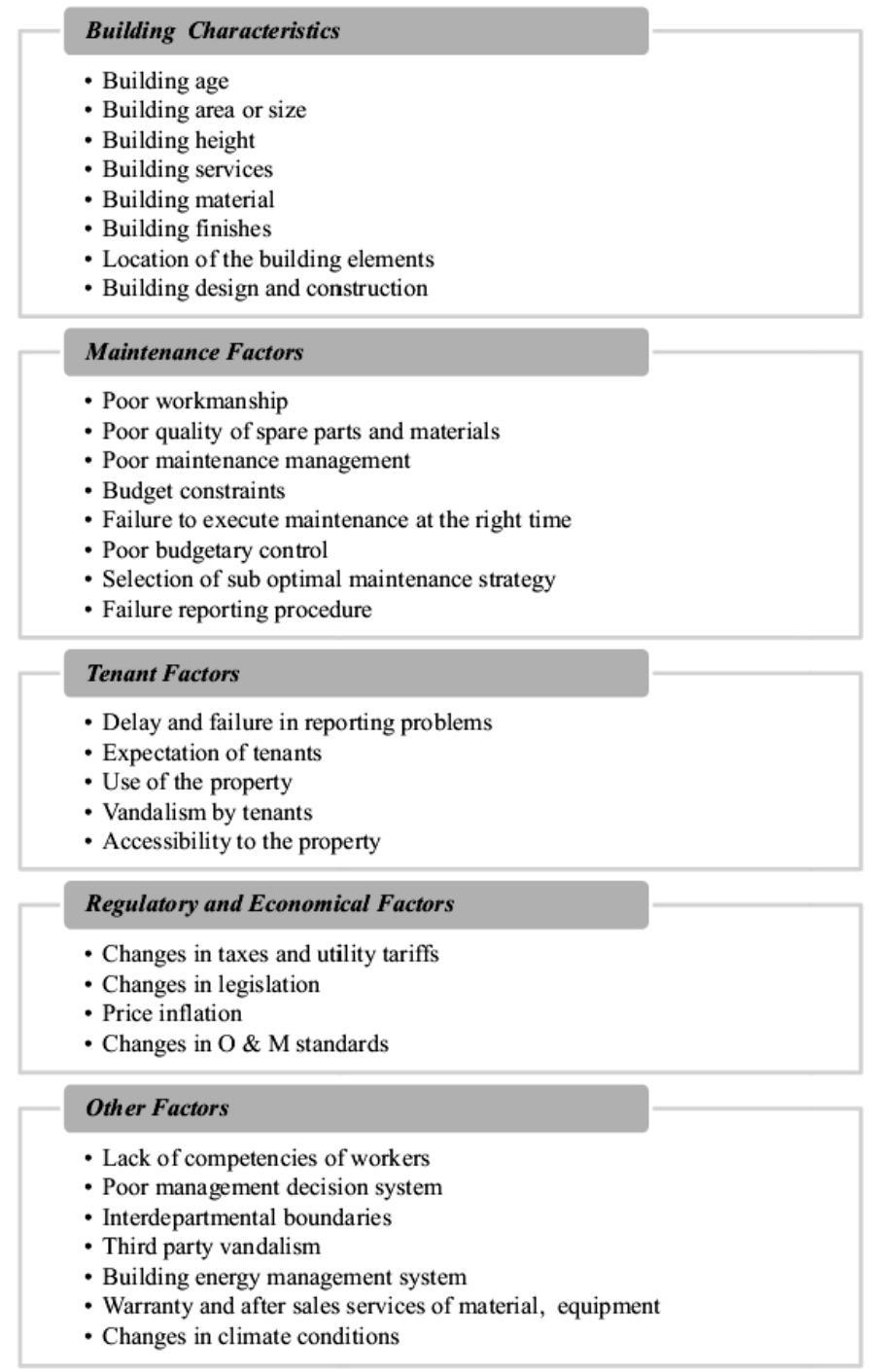

Figure 1: Conceptual Framework of the Determinants of Condominiums' O \& M Costs 
According to the literature, building characteristics like building age, area, size, height, services, material used, finishes, and design and construction are the main considerations for O\&M costs. Further there were certain maintenance factors such as workmanship, spare parts and material and selection of sub optimal maintenance strategy which are considered as factors affection O\&M costs (Olubodun and Mole, 1999; AlArjani, 1995).

In the perspective of tenants, there can be certain factors which govern the O\&M cost. These are delay and failure reporting problems, standard of usage of the property and accessibility to the property can be considered as tenant factors (Neveset al., 2004; Wong, 2002). This aspect clearly shows that O\&M costs are dependent on many stakeholders and not just the management. Further, regulatory factors such as changes in taxes and utility tariffs and changes in legislation also directly aft the O\&M costs.

Finally, there are many factors, which are general in nature, but yet have a direct impact on the O\&M costs. Poor or lack of training', poor management decisions systems, inter departmental boundaries, third party vandalism and building energy management system are few of those which are other factors. All these are summarized and presented in Figure
1 below after the certain modifications with the details developed from the preliminary survey. Details of the preliminary survey and modifications are illustrated later on in this paper.

Identification of corresponding controlling factors

Ali et al. (2010) have pointed out, the identification of the corresponding controlling actions for the determinants is the best way to minimize the impact of these determinants, which could ultimately bring about a reduction in the $\mathrm{O} \& \mathrm{M}$ costs of condominiums.

Among the ordinary controlling actions of the determinants identified in various studies are: the participation of tenants in the condominium management, availability of property operating manuals, effective maintenance management, allocation of a balanced budget for each maintenance task, and employment of workers with acceptable qualifications (Rydell, 1970; Eisenstadt, 1972; El-Haram and Horner, 2002; Goodman, 2004; Dhillon and Liu, 2006; Lai and Yik, 2008; Ali et al., 2010). Based on the literature, for each sub-factor, controlling actions are identified.

Further, based on these researches, 92 controlling actions were also identified for each sub factor of a determinant of O\&M costs (Refer Table 1). 


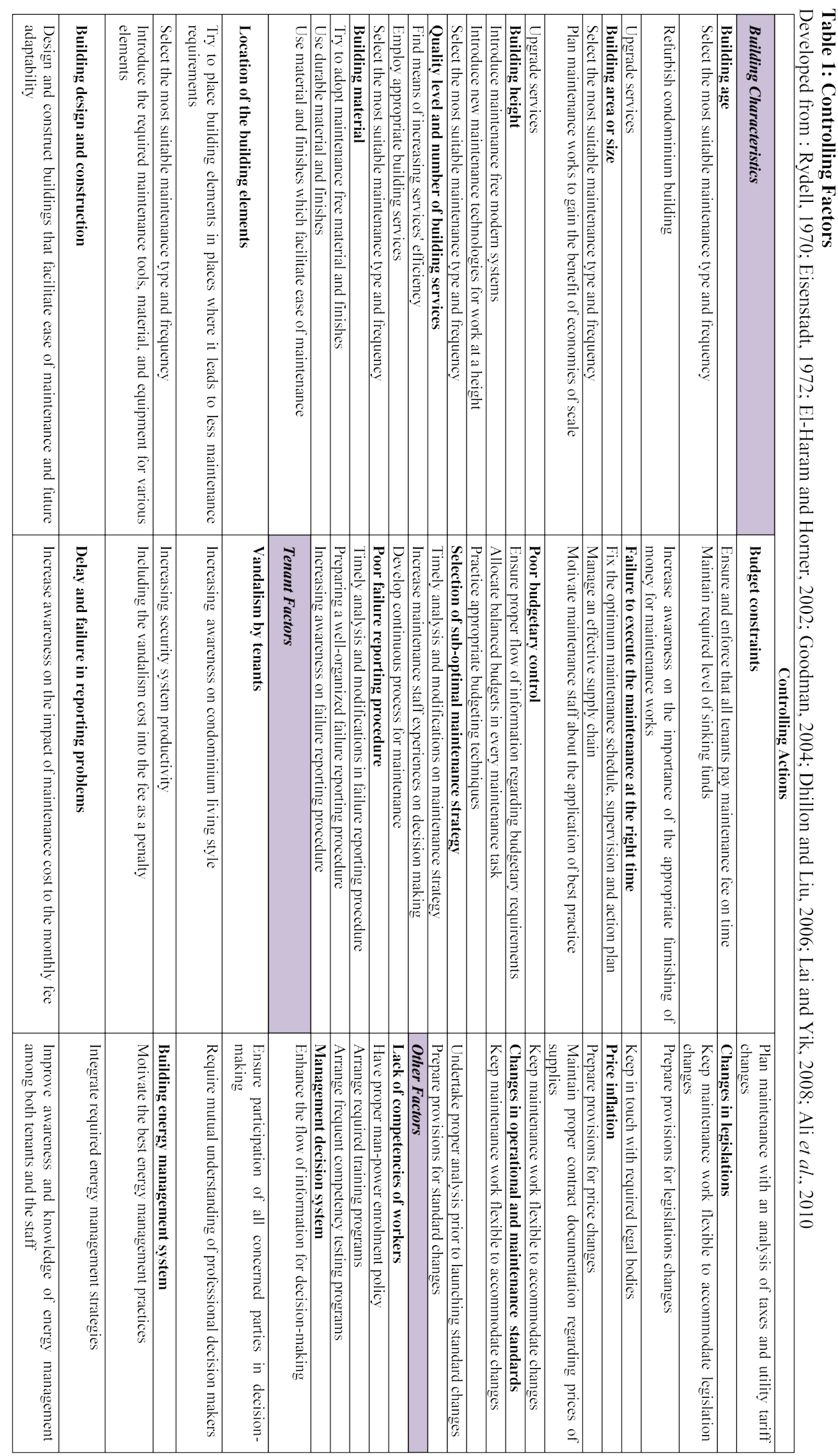


Built-environment: Sri Lanka

Vol. 12, Issue 1, February: 2016

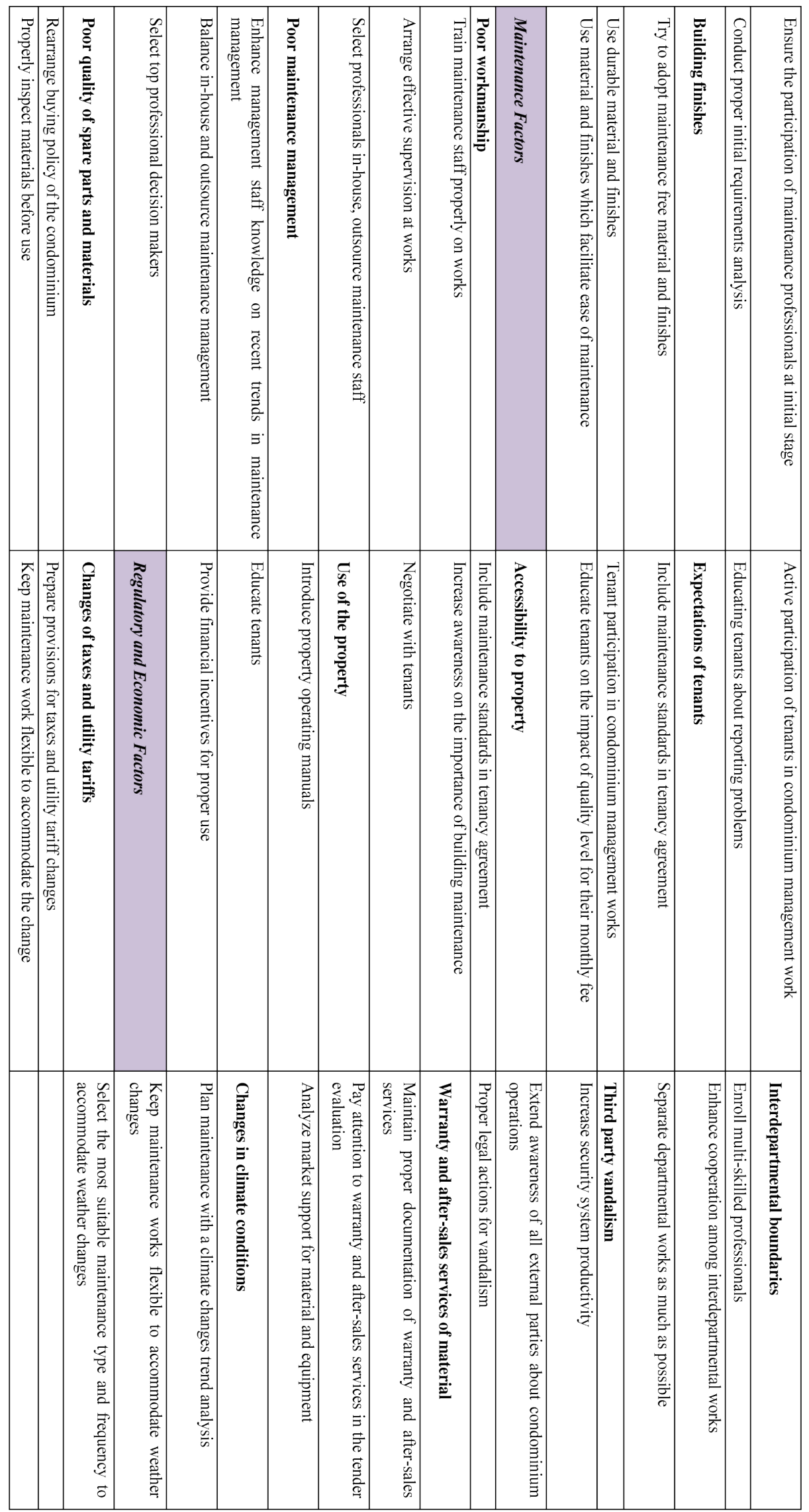




\section{Research Methodology}

The research used a literature survey, a preliminary survey, structured interviews and a questionnaire survey. The factors that affect condominium $\mathrm{O} \& \mathrm{M}$ costs were first identified through the literature survey and summarized. Then a preliminary survey (semi structured interviews) was conducted among six experts from the industry each of whom had more than 20 years of working experience. The preliminary survey was conducted in order to identify the determinants and to develop a conceptual model. Finally a questionnaire survey was carried out among 35 experts from the industry with whom structured interviews were conducted in order to identify the degree of significance of each of the determinants and the controlling actions related to each of the identified determinants.

The analytic part of the research was conducted using AHP (Analytical Hierarchy Process), a multi-criteria decision making tool and RII (Relative Important Index). The AHP tool was used because it could be used to simplify the complex interactions between the thirty-two determinant criteria of the research into simple pair-wise comparisons and since it is much better than the other available multi-criteria decision making tools. Since the development of the framework for the determinants and controlling actions of the $\mathrm{O} \& \mathrm{M}$ costs of condominiums heavily depend on subjective judgements, AHP was identified as the most suitable multi-criteria decision making tool in order to convert those subjective judgements into numerical data (Lam and Zhao, 1998; Cheng and Li, 2001; Day, 2002; Celik et al., 2007; Macharis et al., 2004; Zahir, 1999).

The determinants of $\mathrm{O} \& \mathrm{M}$ costs were prioritized according to the AHP technique while the prioritizing of controlling actions was done using RII as other researchers such as El-Haram and Horner (2002), Johnson (2000), Jeyamathan (2005), Wang et al. (2000), Thomas et al. (2003), and Ali et al. (2010) who had done similar studies have also adopted RII to rank factors.

\section{Research Findings}

\section{Details of the Questionnaire Survey}

Thirty-five questionnaires were distributed among well-experienced representatives of the condominium management industry who formed a fair sample of various professions involved with condominium management. As shown in Table 1, out of the 35 responses received 31 were found to be useful and valid for the analysis. The response rate was high (89\%) probably due to the reason that all 35 questionnaires were hand delivered to the respondents with their consents obtained over the telephone and with formal appointments made.

Table 2: Respondents by Category in the Secondary Data Collection

\begin{tabular}{lc}
\hline Profession Category & Number of Respondents \\
\hline Resident Manager & 10 \\
Chief Engineer & 06 \\
Maintenance Manager & 04 \\
Civil Engineer & 03 \\
Mechanical Engineer & 03 \\
Electrical Engineer & 03 \\
Facilities Manager & 02 \\
Total & $\mathbf{3 1}$ \\
\hline
\end{tabular}




\section{Findings of Preliminary Survey}

A model was developed from literature findings and the conceptual frame work outlined in Figure 1 was developed with the aid of the preliminary survey by modifying the model developed with literature. During the preliminary survey, this theoretical model was extended to form a conceptual framework by removing and altering several existing factors, adding new factors and broadening the scopes of the main factors to ensure the evaluation of the $\mathrm{O} \& \mathrm{M}$ costs of the condominiums in a broader context.

The sub factors identified from the literature review under the main factor 'building characteristics'wereaccepted by all the industry representatives as relevant and appropriate. However, to suit local perspectives, the sub factor, 'type of structure', was replaced with a new sub factor named 'location of the building elements'.

All seven sub factors which were identified from the literature review under 'maintenance factors' were strongly recommended by all the interviewees. 'Failure reporting procedure' was suggested as a new sub factor under this category and the sub factors 'delays and failures in reporting problems', 'expectations of tenants', 'use of the property', 'vandalism by tenants', and 'accessibility to property' were acknowledged by all the industry representatives as factors that should come under ' tenant factors', and in their view the sub factor 'tenant's complaints through different channels' was not applicable to local condominiums as at present.
The main category identified as 'political factors' through the literature was renamed as 'regulatory and economic factors' and two new sub factors , 'price inflation' and 'changes in $\mathrm{O} \& \mathrm{M}$ standards' were introduced in to it after the preliminary survey .

All industry representatives accepted most of the sub factors listed under the 'other factors' category but suggested the replacement of the sub factor 'poor or lack of training' with the sub factor named 'lack of competencies of workers'. Sub factors 'building energy management system' and 'warranty and after sales services' were added to the 'other factors' category. As the literature does not provide any provisions for the changes of climatic conditions, the suggestion to introduce a new sub factor under the heading 'other factors' to evaluate the impact of the changes of climate conditions to condominium $\mathrm{O} \& \mathrm{M}$ costs was accepted. The conceptual framework illustrated in Figure 1 is a result of these important suggestions made by the respondents along with the information obtained through the literature review.

\section{Identification of Significant Determinants of Sri Lankan Condominiums' O \& M Costs}

Using a structured questionnaire, the respondents were asked to identify the degree of importance of the main categories identified through the preliminary survey. This exercise was extended also to the sub-factors under each main factor. Table 2 shows the ranking of the determinants based on their significance to the $\mathrm{O} \& \mathrm{M}$ costs of condominiums. 
Table 3: Significance of Determinants to Condominiums' Operational and Maintenance Cost

\begin{tabular}{|c|c|c|c|c|}
\hline Main Factors and Sub-Factors & $\begin{array}{c}\text { Individual } \\
\text { Significance }\end{array}$ & $\begin{array}{l}\text { Ind. } \\
\text { Rank }\end{array}$ & $\begin{array}{c}\text { Overall } \\
\text { Significance }\end{array}$ & Over. Rank \\
\hline \multicolumn{3}{|l|}{ Building Characteristics } & 0.3522 & 01 \\
\hline Building services & 0.1867 & 01 & 0.0657 & 02 \\
\hline Building finishes & 0.1825 & $\mathbf{0 2}$ & 0.0643 & 03 \\
\hline Building age & 0.1778 & 03 & 0.0626 & 04 \\
\hline Building area or size & 0.1188 & 04 & 0.0418 & $\mathbf{0 7}$ \\
\hline Building material & 0.1088 & 05 & 0.0383 & 09 \\
\hline Building height & 0.0954 & 06 & 0.0336 & 14 \\
\hline Building design and construction & 0.0796 & 07 & 0.0280 & 18 \\
\hline Location of the building elements & 0.0505 & 08 & 0.0178 & 24 \\
\hline \multicolumn{3}{|l|}{ Maintenance Factors } & 0.2244 & 03 \\
\hline Execution of maintenance at right time & 0.1621 & 01 & 0.0364 & 11 \\
\hline Budgetary constraints & 0.1559 & $\mathbf{0 2}$ & 0.0350 & 13 \\
\hline Poor quality of spare parts and materials & 0.1490 & $\mathbf{0 3}$ & 0.0334 & 15 \\
\hline Poor workmanship & 0.1466 & 04 & 0.0329 & 16 \\
\hline Poor budgetary control & 0.1341 & 05 & 0.0301 & 17 \\
\hline Poor maintenance management & 0.0972 & 06 & 0.0218 & 20 \\
\hline Sub-optimal maintenance strategy & 0.0905 & $\mathbf{0 7}$ & 0.0203 & 22 \\
\hline Failure reporting procedure & 0.0646 & 08 & 0.0145 & 27 \\
\hline \multicolumn{3}{|l|}{ Tenant Factors } & 0.2265 & 02 \\
\hline Expectation of tenants & 0.3111 & 01 & 0.0705 & $\mathbf{0 1}$ \\
\hline Use of the property & 0.1987 & 02 & 0.0450 & 05 \\
\hline Accessibility to property & 0.1979 & $\mathbf{0 3}$ & 0.0448 & 06 \\
\hline Delay and failure in reporting problems & 0.1758 & 04 & 0.0398 & 08 \\
\hline Vandalism by tenants & 0.1165 & 05 & 0.0264 & 19 \\
\hline \multicolumn{3}{|l|}{ Regulatory and EconomicFactors } & 0.1147 & 04 \\
\hline Price inflation & 0.3215 & 01 & 0.0369 & 10 \\
\hline Changes in taxes and utility tariffs & 0.3123 & 02 & 0.0358 & 12 \\
\hline Changes in $\mathrm{M} \& \mathrm{O}$ standards & 0.1897 & 03 & 0.0218 & 21 \\
\hline Changes in legislation & 0.1765 & 04 & 0.0203 & 23 \\
\hline \multicolumn{3}{|l|}{ Other Factors } & 0.0822 & 05 \\
\hline Building energy management system & 0.2003 & 01 & 0.0165 & 25 \\
\hline Poor management decision system & 0.1810 & 02 & 0.0149 & 26 \\
\hline Lack of competencies of workers & 0.1581 & $\mathbf{0 3}$ & 0.0130 & 28 \\
\hline Warranty and after-sales services of material & 0.1328 & 04 & 0.0109 & 29 \\
\hline Interdepartmental boundaries & 0.1271 & 05 & 0.0104 & 30 \\
\hline Changes in climate conditions & 0.1022 & 06 & 0.0084 & 31 \\
\hline Third party vandalism & 0.0986 & 07 & 0.0081 & 32 \\
\hline
\end{tabular}

Based on AHP calculations, the categories which have a significant effect on O\&M costs were identified and their sub factors were also ranked. This is illustrated in Table 2. The individual rankings given in Table 2 relates to the ranking of sub factors under each main category.

\section{Importance of sub factors}

According to the overall significance level of the determinants of the $\mathrm{O} \& \mathrm{M}$ costs of condominiums (Table 2), 'expectation of tenants' has become the most important subfactor with a 0.0705 relative determinant score. In fact, the demand made by tenants for a better life style or a living environment is rapidly increasing. This phenomenon has led to the need for maintenance and a corresponding rise in $O \& M$ costs. The second most important sub-factor is the 'building services' with a 0.0657 determinant score. According to Ali et al. (2010), the building services maintenance cost is relatively high as it covers 20 to 45 per cent of the total building running cost. This 
statement is verified by its high determinant score of 0.0657 .

'Building finishes' has been rated as the third most important sub-factor that controls the $\mathrm{O}$ \& $M$ costs of condominiums with a 0.0643 determinant score. This research finding confirms previous studies by Shabha (2003) who discusses how incompatible and poor building finishes can cause deterioration or defects in building components resulting in a high maintenance cost for repairing or replacing such components. The age of the building was the fourth ranked subfactor affecting the control of $\mathrm{O} \& \mathrm{M}$ costs of condominiums. According to Horner et al.(1997), one of the essential elements that needs to be considered in the preparation of maintenance budgets is the age of the building since older buildings would invariable require additional maintenance work. The fourth position allocated to 'building age' in the framework with a 0.0626 determinant score level to support this view.

The fifth important sub-factor controlling the $\mathrm{O} \& \mathrm{M}$ costs of condominiums is the 'use of the property', which has scored (at 0.0450) almost the same relative determinant score as the fourth sub-factor with an insignificant deviation of only 0.0176 . Horner et al. (2008) too identified 'use of the property' as a prominent determinant of condominium running costs due to the unavailability of property operating manuals and proper tenant education about the condominium living environment.

According to El-Haram and Horner (2002), the inability to gain access to the property due to privacy or cultural reasons is one of the major factors that affect condominium maintenance costs. In line with previous research findings, 'accessibility to property' has become the sixth most important sub-factor controlling condominium $\mathrm{O} \& \mathrm{M}$ costs with a 0.0448 relative determinant score.
With a 0.0030 difference from the sixth ranked sub-factor, 'building area or size' has become the seventh important sub-factor with a 0.0418 relative determinant score level. This seventh sub-factor is 0.0239 times more insignificant than the last sub-factor 'tenant expectations'. Thus, early response to building failure would be necessary in order to reduce maintenance costs. However early response to building defects or failure is not possible if there has been a delay and failure in reporting the problems. In accordance with the above outlined scheme in terms of importance, 'delay and failure in reporting problems' is the eighth sub-factor with a 0.0398 determinant score.

By scoring a 0.0383 determinant score level, 'building materials' has become the ninth important sub-factor. This result confirms the observation of Ali et al. (2010) that improper material selection over the life of a facility or a building component is one of the dominant factors affecting condominium $\mathrm{O} \& \mathrm{M}$ costs. 'Price inflation' ranks as the tenth important sub-factor in the investigation of the operational and maintenance costs of condominiums with a 0.0369 determinant score. Thus the sub-factors one to ten varies along a 0.0336 determinant score range. This emphasizes the near equal importance of all the ten sub-factors in the appraisal of condominium running costs. Further, the top 9 sub factors are categorized under the main two categories namely' building characteristics' and' tenant factors'.

\section{Controlling Actions for Determinants of O\&M costs}

The controlling actions were identified through the literature survey and these controlling actions were prioritized in the secondary data collection. During the preliminary survey, the literature findings on controlling actions were upgraded by removing and altering the existing controlling actions, and by adding new controlling actions and broadening the scope 
of the key controlling actions in order to control the $\mathrm{O} \& \mathrm{M}$ costs of condominiums in a logical manner as shown in table 3.

\section{Prioritization of the Controlling Actions of the Determinants}

The Relative Important Index (RII) method was mainly used in order to screen the controlling actions collected from the preliminary survey while the most important controlling actions were identified by arranging the magnitude of RII values in their descending order. Table 4 shows the RII values, ranking positions of controlling actions and the coding system to be adopted in the proposed framework to control the operational and maintenance costs of condominiums in Sri Lanka for all sub factors under each of the main factors. RII creates values ranging from 0 to 1 where 0 denotes least significance and 1 denotes highest significance

Table 4: Prioritization of Controlling Actions of Determinants

\begin{tabular}{|c|c|c|c|}
\hline Controlling Actions & RII & Rank & Code \\
\hline \multicolumn{3}{|l|}{ Building Characteristics } & $\mathbf{A}$ \\
\hline \multicolumn{3}{|l|}{ Building age } & A1 \\
\hline Select the most suitable maintenance type and frequency & 0.794 & 1 & $\mathbf{X}_{1 \mathrm{~A} 1}$ \\
\hline Refurbish condominium building & 0.729 & 2 & $\mathbf{X}_{2 \mathrm{~A} 1}$ \\
\hline Upgrade services & 0.503 & 3 & $\mathbf{X}_{3 \mathrm{~A} 1}$ \\
\hline \multicolumn{3}{|l|}{ Building area or size } & A2 \\
\hline Select the most suitable maintenance type and frequency & 0.748 & 1 & $\mathbf{X}_{1 \mathrm{~A} 2}$ \\
\hline Plan maintenance works to gain the benefit of economies of scale & 0.677 & 2 & $\mathbf{X}_{2 \mathrm{~A} 2}$ \\
\hline Upgrade services & 0.536 & 3 & $\mathbf{X}_{3 \mathrm{~A} 2}$ \\
\hline \multicolumn{3}{|l|}{ Building height } & A3 \\
\hline Introduce maintenance free modern systems & 0.626 & 1 & $\mathbf{X}_{1 \mathrm{A3}}$ \\
\hline Introduce new maintenance technologies for work at a height & 0.554 & 2 & $\mathbf{X}_{2 \mathrm{~A} 3}$ \\
\hline Select the most suitable maintenance type and frequency & 0.542 & 3 & $\mathbf{X}_{3 \mathrm{A3}}$ \\
\hline \multicolumn{3}{|l|}{ Quality level and number of building services } & A4 \\
\hline Find means of increasing services' efficiency & 0.742 & 1 & $\mathbf{X}_{1 \mathrm{A4}}$ \\
\hline Employ appropriate building services & 0.484 & 2 & $\mathbf{X}_{2 \mathrm{~A} 4}$ \\
\hline Select the most suitable maintenance type and frequency & 0.536 & 3 & $\mathbf{X}_{3 \mathrm{A4}}$ \\
\hline \multicolumn{3}{|l|}{ Building material } & A5 \\
\hline Try to adopt maintenance free material and finishes & 0.748 & 1 & $\mathbf{X}_{1 \mathrm{~A} 5}$ \\
\hline Use durable material and finishes & 0.581 & 2 & $\mathbf{X}_{2 \mathrm{~A} 5}$ \\
\hline Use material and finishes which facilitate ease of maintenance & 0.510 & 3 & $\mathbf{X}_{3 \mathrm{~A} 5}$ \\
\hline \multicolumn{3}{|l|}{ Location of the building elements } & A6 \\
\hline $\begin{array}{l}\text { Try to place building elements in places where it leads to less maintenance } \\
\text { requirements }\end{array}$ & 0.652 & 1 & $\mathbf{X}_{1 \mathrm{A6}}$ \\
\hline Select the most suitable maintenance type and frequency & 0.613 & 2 & $\mathbf{X}_{2 \mathrm{~A} 6}$ \\
\hline Introduce the required maintenance tools, material, and ec & 0.555 & 3 & $\mathbf{X}_{3 \mathrm{AB}}$ \\
\hline
\end{tabular}




\begin{tabular}{|c|c|c|c|}
\hline elements & & & \\
\hline Building design and construction & & & A7 \\
\hline $\begin{array}{l}\text { Design and construct buildings that facilitate ease of maintenance and future } \\
\text { adaptability }\end{array}$ & 0.690 & 1 & $X_{1 A 7}$ \\
\hline Ensure the participation of maintenance professionals at initial stage & 0.652 & 2 & $\mathbf{X}_{2 \mathrm{~A} 7}$ \\
\hline Conduct proper initial requirements analysis & 0.606 & 3 & $\mathbf{X}_{3,7}$ \\
\hline Building finishes & & & A8 \\
\hline Try to adopt maintenance free material and finishes & 0.748 & 1 & $\mathbf{X}_{1 \mathrm{~A} 8}$ \\
\hline Use durable material and finishes & 0.639 & 2 & $\mathbf{X}_{248}$ \\
\hline Use material and finishes which facilitate ease of maintenance & 0.529 & 3 & $\mathbf{X}_{348}$ \\
\hline Maintenance Factors & & & B \\
\hline Poor workmanship & & & B1 \\
\hline Train maintenance staff properly on works & 0.703 & 1 & $\mathbf{X}_{1 \mathrm{~B} 1}$ \\
\hline Arrange effective supervision at works & 0.594 & 2 & $\mathbf{X}_{2 \mathrm{~B} 1}$ \\
\hline Select professionals in-house, outsource maintenance staff & 0.536 & 3 & $\mathbf{X}_{3 \mathrm{~B} 1}$ \\
\hline Poor maintenance management & & & B2 \\
\hline $\begin{array}{l}\text { Enhance management staff knowledge on recent trends in maintenance } \\
\text { management }\end{array}$ & 0.607 & 1 & $\mathbf{X}_{1 \mathrm{~B} 2}$ \\
\hline Balance in-house and outsource maintenance management & 0.568 & 2 & $\mathbf{X}_{2 \mathrm{~B} 2}$ \\
\hline Select top professional decision makers & 0.407 & 3 & $\mathbf{X}_{3 \mathrm{~B} 2}$ \\
\hline Poor quality of spare parts and materials & & & B3 \\
\hline Rearrange buying policy of the condominium & 0.729 & 1 & $\mathbf{X}_{1 \mathrm{~B} 3}$ \\
\hline Properly inspect materials before use & 0.639 & 2 & $\mathbf{X}_{2 \mathrm{~B} 3}$ \\
\hline Maintain suppliers' non-conformity records & 0.607 & 3 & $\mathbf{X}_{3 \mathrm{BS} 3}$ \\
\hline Budget constraints & & & B4 \\
\hline Ensure and enforce that all tenants pay maintenance fee on time & 0.632 & 1 & $\mathbf{X}_{1 \mathrm{~B} 4}$ \\
\hline Maintain required level of sinking funds & 0.594 & 2 & $\mathbf{X}_{2 \mathrm{~B} 4}$ \\
\hline $\begin{array}{l}\text { Increase awareness on the importance of the appropriate furnishing of money } \\
\text { for maintenance works }\end{array}$ & 0.568 & 3 & $\mathbf{X}_{3 \mathrm{~B} 4}$ \\
\hline Failure to execute the maintenance at the right time & & & B5 \\
\hline Fix the optimum maintenance schedule, supervision and action plan & 0.677 & 1 & $\mathbf{X}_{1 \mathrm{B5}}$ \\
\hline Manage an effective supply chain & 0.523 & 2 & $\mathbf{X}_{2 \mathrm{~B} 5}$ \\
\hline Motivate maintenance staff about the application of best practice & 0.432 & 3 & $\mathbf{X}_{3 \mathrm{~B} 5}$ \\
\hline Poor budgetary control & & & B6 \\
\hline Ensure proper flow of information regarding budgetary requirements & 0.703 & 1 & $\mathbf{X}_{1 \mathrm{BG}}$ \\
\hline Allocate balanced budgets in every maintenance task & 0.677 & 2 & $\mathbf{X}_{2 \mathrm{~B} 6}$ \\
\hline Practice appropriate budgeting techniques & 0.510 & 3 & $\mathbf{X}_{3 \mathrm{BB}}$ \\
\hline Selection of sub-optimal maintenance strategy & & & B7 \\
\hline Timely analysis and modifications on maintenance strategy & 0.736 & 1 & $\mathbf{X}_{1 \mathrm{~B} 7}$ \\
\hline Increase maintenance staff experiences on decision making & 0.703 & 2 & $\mathbf{X}_{2 \mathrm{~B} 7}$ \\
\hline Develop continuous process for maintenance & 0.542 & 3 & $\mathbf{X}_{3 \mathrm{~B} 7}$ \\
\hline Poor failure reporting procedure & & & B8 \\
\hline Timely analysis and modifications in failure reporting procedure & 0.697 & 1 & $\mathbf{X}_{1 \mathrm{B8}}$ \\
\hline Preparing a well-organized failure reporting procedure & 0.594 & 2 & $\mathbf{X}_{2 \mathrm{BB} 8}$ \\
\hline Increasing awareness on failure reporting procedure & 0.542 & 3 & $\mathbf{X}_{3 \mathrm{BB} 8}$ \\
\hline Tenant Factors & & & $\mathrm{C}$ \\
\hline Vandalism by tenants & & & C1 \\
\hline Increasing awareness on condominium living style & 0.703 & 1 & $\mathbf{X}_{1 \mathrm{C1}}$ \\
\hline Increasing security system productivity & 0.542 & 2 & $\mathbf{X}_{2 \mathrm{C} 1}$ \\
\hline Including the vandalism cost into the fee as a penalty & 0.484 & 3 & $\mathbf{X}_{3 \mathrm{C} 1}$ \\
\hline Delay and failure in reporting problems & & & C2 \\
\hline Increase awareness on the impact of maintenance cost to the monthly fee & 0.781 & 1 & $\mathbf{X}_{1 \mathrm{C} 2}$ \\
\hline Active participation of tenants in condominium management work & 0.658 & 2 & $\mathbf{X}_{2 \mathrm{C} 2}$ \\
\hline Educating tenants about reporting problems & 0.594 & 3 & $\mathbf{X} 3_{\mathrm{C} 2}$ \\
\hline
\end{tabular}




\begin{tabular}{|c|c|c|c|}
\hline \multicolumn{3}{|l|}{ Expectations of tenants } & \multirow{2}{*}{\begin{tabular}{c|c|c|}
$\mathbf{C 3}$ \\
$\mathbf{X}_{1 \mathrm{C} 3}$ \\
\end{tabular}} \\
\hline Include maintenance standards in tenancy agreement & 0.703 & 1 & \\
\hline Tenant participation in condominium management works & 0.690 & 2 & $\mathbf{X}_{2 \mathrm{C} 3}$ \\
\hline Educate tenants on the impact of quality level for their monthly fee & 0.568 & 3 & $\mathbf{X}_{3 \mathrm{C} 3}$ \\
\hline \multicolumn{3}{|l|}{ Accessibility to property } & $\mathbf{C 4}$ \\
\hline Include maintenance standards in tenancy agreement & 0.794 & 1 & $\mathbf{X}_{1 \mathrm{C} 4}$ \\
\hline Increase awareness on the importance of building maintenance & 0.639 & 2 & $\mathbf{X}_{2 \mathrm{C} 4}$ \\
\hline Negotiate with tenants & 0.503 & 3 & $\mathbf{X}_{3 \mathrm{C} 4}$ \\
\hline \multicolumn{3}{|l|}{ Use of the property } & C5 \\
\hline Introduce property operating manuals & 0.690 & 1 & $\mathbf{X}_{1 \mathrm{C} 5}$ \\
\hline Educate tenants & 0.497 & 2 & $\mathbf{X}_{2 \mathrm{C} 5}$ \\
\hline Provide financial incentives for proper use & 0.400 & 3 & $\mathbf{X}_{3 \mathrm{C} 5}$ \\
\hline \multicolumn{3}{|l|}{ Regulatory and Economic Factors } & D \\
\hline \multicolumn{3}{|l|}{ Changes of taxes and utility tariffs } & D1 \\
\hline Prepare provisions for taxes and utility tariff changes & 0.736 & 1 & $\mathbf{X}_{1 \mathrm{D1}}$ \\
\hline Keep maintenance work flexible to accommodate the change & 0.568 & 2 & $\mathbf{X}_{2 \mathrm{D} 1}$ \\
\hline Plan maintenance with an analysis of taxes and utility tariff changes & 0.465 & 3 & $\mathbf{X}_{3 \mathrm{DD1}}$ \\
\hline \multicolumn{3}{|l|}{ Changes in legislations } & D2 \\
\hline Keep maintenance work flexible to accommodate legislation changes & 0.677 & 1 & $\mathbf{X}_{1 \mathrm{D} 2}$ \\
\hline Prepare provisions for legislations changes & 0.587 & 2 & $\mathbf{X}_{2 \mathrm{D} 2}$ \\
\hline Keep in touch with required legal bodies & 0.516 & 3 & $\mathbf{X}_{3 \mathrm{D} 2}$ \\
\hline \multicolumn{3}{|l|}{ Price inflation } & D3 \\
\hline Prepare provisions for price changes & 0.723 & 1 & $\mathbf{X}_{1 \mathrm{ID3}}$ \\
\hline Maintain proper contract documentation regarding prices of supplies & 0.684 & 2 & $\mathbf{X}_{2 \mathrm{D} 3}$ \\
\hline Keep maintenance work flexible to accommodate changes & 0.510 & 3 & $\mathbf{X}_{3 \mathrm{DB}}$ \\
\hline \multicolumn{3}{|l|}{ Changes in operational and maintenance standards } & D4 \\
\hline Keep maintenance work flexible to accommodate changes & 0.723 & 1 & $\mathbf{X}_{1 \mathrm{ID4}}$ \\
\hline Undertake proper analysis prior to launching standard changes & 0.581 & 2 & $\mathbf{X}_{2 \mathrm{D} 4}$ \\
\hline Prepare provisions for standard changes & 0.458 & 3 & $\mathbf{X}_{3 \mathrm{D} 4}$ \\
\hline \multicolumn{3}{|l|}{ Other Factors } & $\mathbf{E}$ \\
\hline \multicolumn{3}{|l|}{ Lack of competencies of workers } & E1 \\
\hline Have proper man-power enrolment policy & 0.677 & 1 & $\mathbf{X}_{1 \mathrm{E} 1}$ \\
\hline Arrange required training programs & 0.497 & 2 & $\mathbf{X}_{2 \mathrm{E} 1}$ \\
\hline Arrange frequent competency testing programs & 0.400 & 3 & $\mathbf{X}_{3 \mathrm{E} 1}$ \\
\hline \multicolumn{3}{|l|}{ Management decision system } & E2 \\
\hline Enhance the flow of information for decision-making & 0.677 & 1 & $\mathbf{X}_{1 \mathrm{E} 2}$ \\
\hline Ensure participation of all concerned parties in decision-making & 0.542 & 2 & $\mathbf{X}_{2 \mathrm{E} 2}$ \\
\hline Require mutual understanding of professional decision makers & 0.516 & 3 & $\mathbf{X}_{3 \mathrm{E} 2}$ \\
\hline \multicolumn{3}{|l|}{ Building energy management system } & $\mathbf{E 3}$ \\
\hline Motivate the best energy management practices & 0.761 & 1 & $\mathbf{X}_{1 \mathrm{E} 3}$ \\
\hline Integrate required energy management strategies & 0.632 & 2 & $\mathbf{X}_{2 \mathrm{E} 3}$ \\
\hline $\begin{array}{l}\text { Improve awareness and knowledge of energy management among both } \\
\text { tenants and the staff }\end{array}$ & 0.548 & 3 & $\mathbf{X}_{3 \mathrm{E} 3}$ \\
\hline \multicolumn{3}{|l|}{ Interdepartmental boundaries } & $\mathbf{E 4}$ \\
\hline Enroll multi-skilled professionals & 0.645 & 1 & $\mathbf{X}_{1 \mathrm{E} 4}$ \\
\hline Enhance cooperation among interdepartmental works & 0.497 & 2 & $\mathbf{X}_{2 \mathrm{E} 4}$ \\
\hline Separate departmental works as much as possible & 0.387 & 3 & $\mathbf{X}_{3 \mathrm{E} 4}$ \\
\hline \multicolumn{3}{|l|}{ Third party vandalism } & E5 \\
\hline Increase security system productivity & 0.677 & 1 & $\mathbf{X}_{1 \mathrm{E} 5}$ \\
\hline Extend awareness of all external parties about condominium operations & 0.555 & 2 & $\mathbf{X}_{2 \mathrm{E} 5}$ \\
\hline Proper legal actions for vandalism & 0.445 & 3 & $\mathbf{X}_{3 \mathrm{E} 5}$ \\
\hline \multicolumn{3}{|l|}{ Warranty and after-sales services of material } & E6 \\
\hline Maintain proper documentation of warranty and after-sales services & 0.645 & 1 & $\mathbf{X}_{1 \mathrm{E} 6}$ \\
\hline Pay attention to warranty and after-sales services in the tender evaluation & 0.548 & 2 & $\mathbf{X}_{2 \mathrm{E} 6}$ \\
\hline Analyze market support for material and equipment & 0.516 & 3 & $\mathbf{X}_{3 \mathrm{E} 6}$ \\
\hline
\end{tabular}




\begin{tabular}{|l|c|c|c|}
\hline Changes in climate conditions & E7 \\
\hline Plan maintenance with a climate changes trend analysis & 0.587 & $\mathbf{1}$ & $\mathbf{X}_{\mathbf{1 E 7}}$ \\
\hline Keep maintenance works flexible to accommodate weather changes & 0.542 & $\mathbf{2}$ & $\mathbf{X}_{\text {2E7 }}$ \\
\hline $\begin{array}{l}\text { Select the most suitable maintenance type and frequency to accommodate } \\
\text { weather changes }\end{array}$ & 0.465 & $\mathbf{3}$ & $\mathbf{X}_{\text {3E7 }}$ \\
\hline
\end{tabular}

According to the above table majority of the factors except for thirteen control actions, all the others reported a RII of greater than 0.5 marks. For most of the sub factors there were controlling actions available which has gained a RII value more than .70 marks. This clearly shows that, there are reliable controlling actions which can be put into place to regulate that $O \& M$ costs. However when main criteria are considered, "other factors" has the lowest RII scores. This reports that these factors are rather difficult to control compared with the other defined main factors. Factors like lack of competencies of workers, management decision systems, interdepartmental boundaries, third party boundaries, warranty and after sales services and changes in climatic conditions gained lower RII values for the respective controlling actions. In these O\&M factors, there was no any controlling action which derived significance greater than 0.7 marks. Further, all these factors are categorised as other factors.

However, when considering the above table, it is notable that all the factors affecting O\&M cost had certain controlling actions which can be put into practice. Therefore, all these above given factors are considered in the framework to control the O\&M costs.

\section{Framework to Control the Operational and Maintenance Costs of Condominiums}

The ultimate objective of this study was to develop a framework providing a firm basis to control the operational and maintenance costs of condominiums built in Sri Lanka using the individual and overall significance of determinants and the corresponding prioritized actions under each determinant. The framework so developed is indicated in Figure 2 which is in the form of a modified fish bone diagram. The leg- end to the framework is also given in Figure 2 with the coding system to the framework given in Table 3.

In Figure 2, the arrows which are pointed towards the rectangle named 'operational and maintenance costs of condominiums' from rectangles such as $\mathrm{A}, \mathrm{A} 1$, and $\mathrm{B} 8$ indicate how operational and maintenance costs of the local condominiums are increased due to the effects of determinants. The arrows which are pointed towards the triangles from smaller rectangles such as A1, D3, and C3 demonstrate the means of controlling the effects of determinants on the operational and maintenance costs of these condominiums. However, the triangular nodes which are directed away from smaller rectangles show the more important controlling measures whereas the triangular nodes which are directed towards smaller rectangles show the lesser important measures that can control the operational and maintenance costs of local condominiums.

By referring to this Model, it is possible to identify not only the most important main factors but also the sub-factors of those main factors that are important, both individually and as a whole along with three controlling actions that too are ranked in the Sri Lankan context in respect of each sub-factor. All the determinants and corresponding controlling actions are vital in order to control or reduce the operational and maintenance costs of condominiums. However, since it is not practical to consider the controlling actions of all determinants all at once, it would be better to address the smaller highlighted rectangles such as A1, $\mathrm{C} 1$, and $\mathrm{C} 2$ initially by adopting the highlighted controlling actions. These two highlighted categories provide the most significant determinants of O\&M costs and the respective controlling actions as illustrated in Table 2 and 3 respectively. 
Built-environment: Sri Lanka

Vol. 12, Issue 1, February: 2016

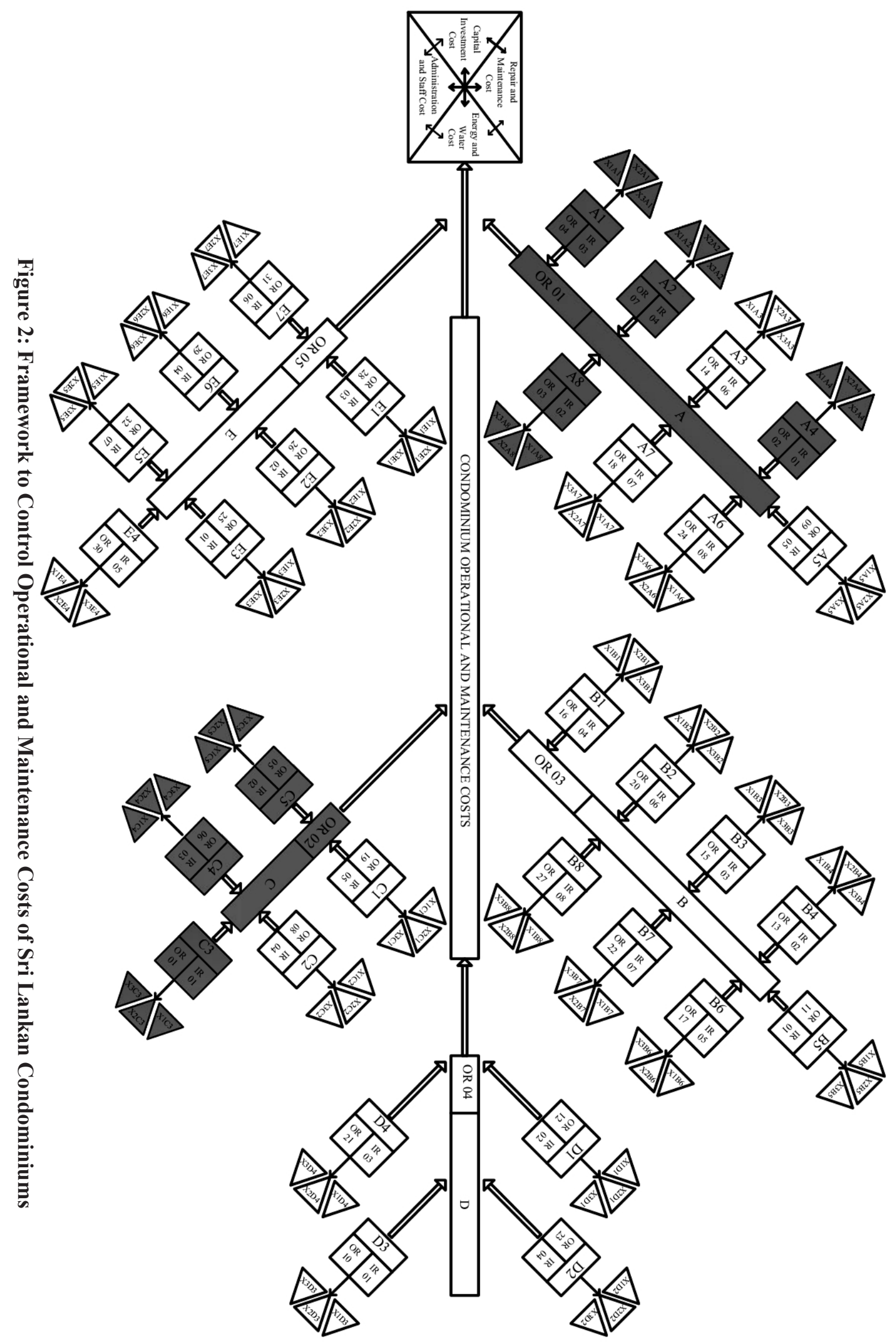




\section{Conclusions and Recommendations}

This study offers a framework to control the operational and maintenance costs of condominiums built in Sri Lanka prepared by tabulating their determinants in the order of their priority together with their controlling actions. (see Tables 3 and 4). The proposed framework(Figure2)indicatesthemostrational way of reducing or controlling operational and maintenance costs of condominiums. This study identifies 32 dominant determining factors under five main categories. Further 92 controlling actions have also been identified. Therefore it is recommended to follow the framework and initially identify the relevant controlling action to the relevant sub factor. Then based on the most significant controlling action can be put into action in order to regulate the O\&M cost. Further, according to the framework there are several controlling actions are illustrates. Further, it is organized in a way to identify the most to the least significant. Therefore, when implementing the framework it is ideal to implement the most significant in the first instance. However still it will not be practical to put in to practice all the controlling mechanisms. The highlighted options of the framework should be given priority as the corresponding determinants and their controlling actions will have the most significant impact on the O\&M costs.

With reference to the data analysis, 'building characteristics' have the most significant determinants for the O\&M costs. Most of these building characteristics can be selected at the design stage of the project itself so that their impact on O\&M costs could be minimized. It can also be concluded that O\&M costs have to be given proper consideration at the initial stages of the project itself. Finally, it is necessary to conclude that O\&M costs are based on many factors. Most of these factors are controllable to a greater extent except to a very few.

\section{Limitations and further research}

This framework is not been tested in the actual scenario and purely based on the findings of the study. Therefore, lack of practical implementation would be the most significant limitation of the study. Therefore, researchers recommend adopting this framework to an actual condominium in Sri Lanka and further developing it in the actual real life context with modifications

\section{References}

Al-Arjani, A.H., 1995. Impact of cultural issues on the scheduling of housing maintenance in a Saudi Arabian urban project. International journal of project management, 13 (6), 373382.

Al-Hammad, A., Al-Mubaiyadh, S. and Mahmoud, T., 1996. Public versus private sector's assessment of problems facing the building maintenance industry in Saudi Arabia. Building research \& information, 24 (4), 245254.

Ali, A.S., 2009. Cost decision making in building maintenance practice in Malaysia. Journal of facilities management, 7(4), 298306.

Ali, A.S., Kamaruzzaman, S.N., Sulaiman, R. and Peng, Y.C., 2010. Factors affecting housing maintenance cost in Malaysia. Journal of facilities management, 8 (4), 285-298.

Ariyawansa, R.G., 2007. An empirical study of consumer behavior in housing market in Colombo. Built environment Sri Lanka, 8(1), 11-19.

Bardey, D., Riane, F., Artiba, A. and Eeckhoudt, L., 2005. To maintain or not to maintain? what should a risk-averse decision maker do?. Journal of quality in maintenance engineering, 11 (2), 115-120. 
Burrell, Q.L., 1985. The 80/20 rule: library lore or statistical law?,Journal of documentation, 41(1), $24-39$.

Cheng, E.W.L and Li, H., 2001. Information priority-setting for better resource allocation using analytic hierarchy process (AHP). Information management and computer security, 9 (2), 61-70.

Cheung, M.S. and Kyle, B.R., 1996. Service life prediction of concrete structures by reliability analysis. Construction and building materials, 10 (1), 45-55.

Cleik, M., Er, I.D and Ozok, A.F., 2007. Application of fuzzy extended AHP methodology on shipping registry selection: the case of Turkish maritime industry. Expert systems with applications, 36 (2009), 190198.

Day, P.K., 2002. Project risk management: a combined analytic hierarchy process and decision tree approach. Cost engineering, 44 (3), 13-26.

Dhillon, B.S. and Liu, Y., 2006. Human error in maintenance: a review. Journal of quality in maintenance, 12 (1), 21 - 36.

Edirimane, A., 2006. Understanding the concept of condominiums, Colombo: Ceylon Printed Ltd.

Eisenstadt, K.M., 1972. Factors affecting maintenance and operating costs in private rental housing. New York, New York City Rand Institute.

El-Haram, M.A. and Horner, M.W., 2002. Factors affecting housing maintenance cost. Journal of quality in maintenance engineering, 8 (2), 115-123.
Emma, M.A.Z. and Syahrul, N.K., 2009. Personnel characteristics of maintenance practice: a case of high-rise office buildings in Malaysia. Journal of sustainable development, 2 (1), 111-116.

Goodman, J., 2004. Determinants of operating costs of multifamily rental housing. Harvard: Joint Center for Housing Studies of Harvard University.

Horner, R.M.W., El-Haram, M.A. and Munns, A.K., 1997. Building maintenance strategy: a new management approach. Journal of quality in maintenance engineering,3 (4), 273-280.

Jeyamathan, S.J., 2005. Identifying and Analyzing Duties and Skills of Quantity Surveyors in Sri Lanka, Unpublished undergraduate dissertation, Department of building economics, University of Moratuwa, Sri Lanka.

Johnson, A.J.J., 2000. Project manager which services characteristics and skills are essential and could it be a quantity Surveyor? Unpublished undergraduate dissertation, Department of building economics, University of Moratuwa, Sri Lanka.

Komonen, K., 2002. A cost model of industrial maintenance for profitability analysis and benchmarking. International journal of production economics, 79 (1), 15-31.

Khalid, K., Marosszeky, M. and Davis, S., 2006. Managing subcontractor supply chain for quality in construction. Engineering, construction and architectural management, 13 (1), 27-42.

Lai, J.H.K. and Yik, F.W.H., 2008. Benchmarking operation and maintenance cost of luxury hotels. Journal of facilities management, 6 (4), 279-289. 
Lam, K and Zhao, X., 1998. An application of quality function development to improve the quality to teaching. International journal of quality and reliability management, 15 (4), 389-413.

Lee, H.H.Y. and Scott, D., 2009. Overview of maintenance strategy, acceptable maintenance standard and resources from a building maintenance operation perspective. Journal of building appraisal, 4 (4), 269-278.

Love, P.E.D. and Irani, Z., 2003. A project management quality cost information system for the construction industry. Information \& management, 40 (7), 649-661.

Macharis, C., Springael J., De Brucker, K., Verbeke, A. 2004: Promethee and AHP: The design of operational synergies in multicriteria analysis. Strengthening Promethee with ideas of AHP. European Journal of Operational Research 153: 307-317.

Neves, L.C., Frangopol, D.M. and Cruz, P.S., 2004. Cost of life extension of deteriorating structures under reliability-based maintenance. Computers and structures, 82 (13/14), 10771089.

O'Neill, D., 1974. The determinants of housing cost. Architects journal, 3 (1), 753-755.

Olubodun, F. and Mole, T., 1999. Evaluation of defect influencing factors in public housing in the UK. Structural survey, 17 (3), 170-178. Olubodun, F., 2001. A multivariate approach to the prediction of maintenance needs in public housing: the tenant dimension. Structural survey, 19 (2), 133-141.

Pascual, R., Meruane, V. and Rey, P.A., 2008. On the effect of downtime costs and budget constraint on preventive and replacement policies. Reliability engineering \& system safety, 93 (1), 144-151.
Rydell, C.P., 1970. Factors affecting maintenance and operating costs in Federal public housing projects. New York: New York City Rand Institute.

Sampath, D.B.D., 2011. Problems faced by occupants in utility condominiums in Sri Lanka, Unpublished undergraduate dissertation, Department of building economics, University of Moratuwa, Sri Lanka.

Senaratne, S., Zainudeen, N. and Wedikkara, C., 2006. Factors affecting condominium development in Sri Lanka. Built environment Sri Lanka, 7 (1), 23-28.

Shabha, G., 2003. A low-cost maintenance approach to high-rise flats. Facilities, 21 (3/14), 315-322.

Simoes, J.M., Gomes, C.F. and Yasin, M.M., 2011. A literature review of maintenance performance measurement. Journal of quality in maintenance engineering, 17 (2), 116-137.

Skinner, N.P., 1982. Local authority house maintenance - the variation in expenditure. Housing review, 31 (1), 92-94.

Sliteen, S., Boussabaine, H. and Catarina, O., 2011. Benchmarking operation and maintenance costs of French healthcare facilities. Journal of facilities management, 9 (4), 266-281.

Stoy, C. and Kytzia, S., 2008. Utility costs: a survey of Swiss office building. Journal of facilities management, 6 (2), 120-131.

Thomas, A.V., Kalidid, S.N. and Ananthanarayan, K., 2003. Risk perception analysis of BOT road project participants in India. Construction management and economics, 21 (4), 393-407. 
Thompson, P., 1994. The maintenance factor in facilities management. Facilities, 12 (6), 1316.

Wang, S.Q., Tiong, R.L.K., Ting, S.K., and Ashley, D., 2000. Evaluation and management of political risks to China's BOT projects. ASCE journal of construction engineering and management, 126 (3), 242-250.

Williams, B., 1996. Cost effective facilities management: a practical approach. Facilities, 14 (6), 26-38.

Wong, L.T., 2002. A cost model for plumbing and drainage systems. Facilities, 20 (11/12), 386-393.

Wordsworth, P., 2001. Lee's building maintenance management, 4th ed. Oxford: Blackwell Science.
Yip, N.M., 2001. Tenant participation and the management of public housing-the estate management advisory committee of Hong Kong. Property management, 19 (1), 10-18.

Yip, N.M. and Forrest, R., 2002. Property owning democracies? home owner corporations in Hong Kong. Housing studies, 17 (5), 703720 .

Yip, N.M., Chang, C.O. and Hung, T.Y., 2007. Modes of condominium management: a principal-agent perspective. Facilities, 25 (5/6), 215-226.

Zahir, S., 1999: Clusters in group: Decision making in the vector space formulation of the analytic hierarchy process. European Journal 